\title{
Evaluation nutritional of acid silage of Nile tilapia (Oreochromis niloticus), whole fish discarded, farmed in Indaiatuba $-\mathrm{SP}^{1}$
}

\section{Avaliação nutricional da silagem ácida de tilápia do Nilo (Oreochromis niloticus), peixe inteiro descartado, cultivadas em Indaiatuba - SP ${ }^{l}$}

\section{Ronaldo de Oliveira Sales $*^{2}$, Admar Costa de Oliveira ${ }^{3}$}

Part of the Doctoral Thesis of the first author.

${ }^{2}$ Federal University of Ceará - DZ / CCA / UFC. E-mail: ronaldo.sales@ufc.br

${ }^{3}$ State University of Campinas/UNICAMP

* To whom correspondence should be sent- E-mail: ronaldo.sales@ufc.br

\begin{abstract}
The continental aquaculture with a production of $210,644,500$ thousand tonnes produces a volume of solid waste causing a serious environmental problem, where $20 \%$ of the fish caught gets lost for lack of storage. The ideal would be to use raw materials and to recover byproducts as ingredients for animal feed. Aiming to increase the income and the capacity of production and, thus, to minimize environmental and health problems, deriving from fish waste, it was prepared the acid silage of the whole fish discarded from Nile tilapia (Oreocrhromis niloticus) after acidification and homogenisation of the biomass with $3 \%$ of formic acid and maintaining the $\mathrm{pH}$ around 3.7. Analyses were conducted to determine the humidity, protein, lipids and ash. Amino acids were examined in an auto-analyzer after acid hydrolysis, except for tryptophan determined by colorimetry. The new silage of Nile tilapia showed values higher than FAO standards for all essential amino acids, except for tryptophan. The highest values were found for glutamic acid, aspartic acid, lysine, leucine and glycine. The results indicate the potential use of the acid silage, prepared from the whole fish discarded from Nile tilapia, as a protein source in the formulation of animal feed, turning it into an excellent alternative for adding value to biowaste deriving from solid fish waste.
\end{abstract}

Key words: proximate composition, amino acid profile, acid silage, whole fish discarded 
Sales et al., Revista Brasileira de Higiene e Sanidade Animal (v.7, n.2) p. 16 - 30, ago - dez (2013)

RESUMO: A aqüicultura continental com uma produção de 210.644,5 mil toneladas produz um volume de resíduos sólidos causando um sério problema ambiental, onde $20 \%$ do pescado capturado chega a ser perdido por falta de armazenamento. O ideal seria o aproveitamento da matéria prima e recuperação dos subprodutos, como ingredientes para ração animal. Com os objetivos de aumentar a receita e a eficiência de produção e, consequentemente, minimizar os problemas ambientais e de sanidade, provenientes dos resíduos de pescado, procedeu-se à elaboração da silagem ácida do pescado inteiro descartado de tilápia-do-Nilo (Oreocrhromis niloticus) após homogeneização e acidificação da biomassa com 3\% de ácido fórmico e manutenção do pH ao redor de 3,7. Foram realizadas análises para determinação da umidade, proteína, lipídios e cinza. Os aminoácidos foram examinados em autoanalisador após hidrólise ácida, à exceção do triptofano determinado por colorimetria. A silagem nova de tilápia-do-Nilo apresentou valores superiores ao padrão da FAO para todos os aminoácidos essenciais, com exceção do triptofano. Os valores mais elevados encontrados foram para o ácido glutâmico, aspártico, lisina leucina e glicina. Os resultados indicam a utilização potencial da silagem ácida, preparada a partir do pescado inteiro descartado de tilápia-do-Nilo, como fonte protéica na formulação de ração para animais domésticos, tornando-a excelente alternativa, por agregar valor ao biolixo proveniente dos resíduos sólidos do pescado.

Palavras claves: composição centesimal, perfil de aminoácidos, silagem ácida, despesca de pescado

\footnotetext{
* To whom correspondence should be sent- E-mail: ronaldo.sales@ufc.br Received on 20.03.2013. Accepted 10.08.2013
}

\section{Introduction}

Environmental problems caused by large amounts of fish waste can be minimized by transforming such wastes into a product that can be incorporated as an ingredient for animal feed (ARRUDA et al., 2006). An alternative with great potential is the use of catch losses and wastes from fish processing (which can reach $60 \%$ of what is produced and / or captured) for the preparation of fish silage, and noble product 
Sales et al., Revista Brasileira de Higiene e Sanidade Animal (v.7, n.2) p. 16 - 30, ago - dez (2013)

with high biological value, making it a great alternative for adding value to fish waste (OLIVEIRA et al., 2012).

The nutritional value of fish silage is in the high protein digestibility due to the fact that protein is already well hydrolyzed and of the presence of lysine and tryptophan in high concentrations as well as of other essential amino acids. After bioconversion, the product is a high quality autolysed source of protein which can be used in animal feed and in the development of new foods, thus becoming a source of free amino acids and peptides of high quality, hardly obtained by other technological processes (BORGHESE et al., 2008).

It may also be useful as organic fertilizer for the wealth of nutrients resulting from the presence of scales, fur, bones, collagen, blood, fat, swim bladder, gonads, eyes, brains, livers, digestive enzymes and carotenoids (ESPINDOLA FILHO, 1999; BEERLI et al., 2004).

The aim of this study was to evaluate the mineral proximate composition, the profile of amino acid of acid silage of Nile tilapia (Oreochromis niloticus), grown in
Indaiatuba - S.P., as alternative ingredient in feed rations.

\section{Materials and Methods}

The raw material for obtaining the fish chemical silage, consisted of five samples of whole fish discarded of Nile tilapia (Oreochromis niloticus) totaling $5 \mathrm{~kg}$ in each sample, from the commercial cultivation in the region of Indaiatuba, S.P., fragmented in crusher, electrical equipment model ML-4, 0/Weg-uline. Then, it was homogenized, weighed and evenly distributed in hard plastic containers by adding formic acid in the ratio of $3 \%(\mathrm{w} / \mathrm{w})$ of the volume of acid solution to the mass of the residue (BERAQUET \& GALACHO, 1983). The agitation of the material was often held to spread the enzymes and thus accelerate the rate of liquefaction $(\mathrm{MACH}$ DIEP \& NORTVEDT, 2009) with daily pH control obtaining the acid silage of tilapia. Then the material was subjected to a drying process at room temperature for 15 to 20 days to obtain the dried silage with storage for 90 days at $27^{\circ} \mathrm{C} \pm 3{ }^{\circ} \mathrm{C}$ and then it was subjected to the analysis of proximal 

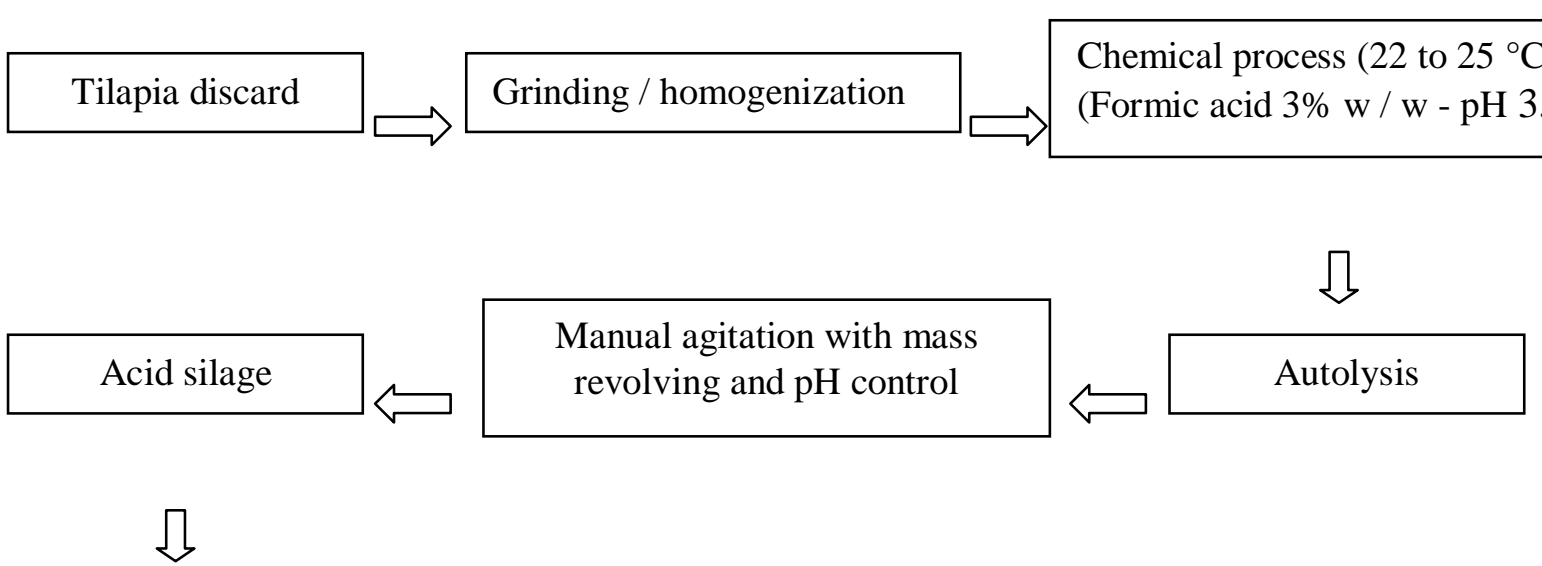

\section{Drying at room temperature} during 15 at 20 days
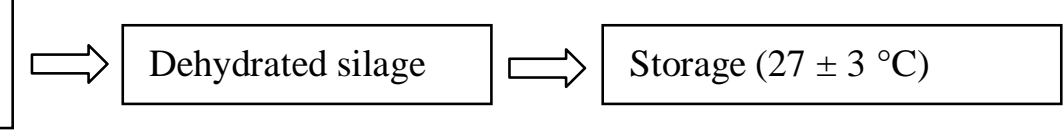

Figure 1. Flowchart processing for preparation of Nile tilapia acid silage

Analyses were conducted to determine the composition of the chemical silage of tilapia. All the tests were performed in triplicate and according to the (AOAC, 2000). Moisture was determined by gravimetric method, in a greenhouse at $105{ }^{\circ} \mathrm{C}$ until constant weight. The protein was calculated by the microKjeldahl method with digestion of organic material in a digester block followed by distillation and titration with $0.01 \mathrm{M}$ sulfuric acid. The lipid fraction was obtained by Soxhlet extractor. It was used petroleum ether as solvent, followed by heating in an rotative evaporator until total removing of the solvent. The ash content was measured gravimetrically treating the sample in a muffle furnace at $550{ }^{\circ} \mathrm{C}$ for incineration of organic matter, and the levels of minerals calciumm, magnesium, iron and phosforous were determined by atomic absorption, spectrophotometry. For quantification of amino acids, samples were hydrolyzed with $6 \mathrm{~N}$ HCL for 22 hours at 110 ${ }^{\circ} \mathrm{C}$ (MOORE \& STEIN, 1963). Samples were analyzed by ionic exchange chromatography in accordance with SPACKMANN et al. (1958), using an automatic analyzer. Tryptophan was determined after enzymatic hydrolysis with Pronase at $40{ }^{\circ} \mathrm{C}$ for 24 hours, followed by colorimetric reaction with 4 - dimethyl - aminobenzaldehyde (ABD) in $21.2 \mathrm{~N}$ sulfuric acid 
Sales et al., Revista Brasileira de Higiene e Sanidade Animal (v.7, n.2) p. 16 - 30, ago - dez (2013)

reading at $590 \mathrm{~nm}$ and is calculation from a standard curve, according to SPIES (1967). The chemical score was determined according to Sgarbieri (1987), through the relationship between the content of each essential amino acid content with the corresponding amino acid of a standard protein NATIONAL ACEDEMY OF SCIENCE (1980). The data were analyzed according to completely randomized design (BARBOSA \& MALDONADO, 2010). For the analysis of variance and means comparison, Tukey test was used at $5 \%$ probability.

\section{Results and Discussion}

There was no significant difference $(\mathrm{P}>0.05)$ in proximate composition between the analyzed batches of Nile tilapia used for preparation of acid silage of fish wastes, with average value $76.62 \%, 17.07 \%, 3.57 \%$ and $2.33 \%$ for moisture, protein, fat and ash, respectively (Table 1). These data are consistent with those reported by Espindola Filho (1999) who, analyzing the composition of cruzamento da Tilapia nilotica (fêmea) com Tilapia hornorum (macho), found out that the moisture was presented into the range of $74.32 \%$ to $75.63 \%$, protein from 17.52 to $17.62 \%$ ash, 1.73 to $2.32 \%$ and lipids 3.75 to $7.48 \%$.

The largest coefficient of variation (CV\%) occurred in the levels of ash with $26.29 \%$, and then to a lesser extent by lipids, with $9.20 \%$ protein, with $2.24 \%$ and finally moisture,with $1.30 \%$.

Similar results were obtained by Sales (1995) that working with different species of Nile tilapia, observed no difference $(\mathrm{P}>0.05)$ among the samples analyzed, with more pronounced variations in ash content $(0.7$ to 4.2 $\%)$, being the lowest in moisture and protein, in which almost all species have similar values and the tilapia can be classified as lean fish (3.25 to $6.26 \%$ ) of high protein content. 
Sales et al., Revista Brasileira de Higiene e Sanidade Animal (v.7, n.2) p. 16 - 30, ago - dez (2013)

Table 1. Proximate composition of Nile tilapia (Oreochromis niloticus), (whole fish with viscera, skin and scales) from Indaiatuba, Sao Paulo, during the discard period.

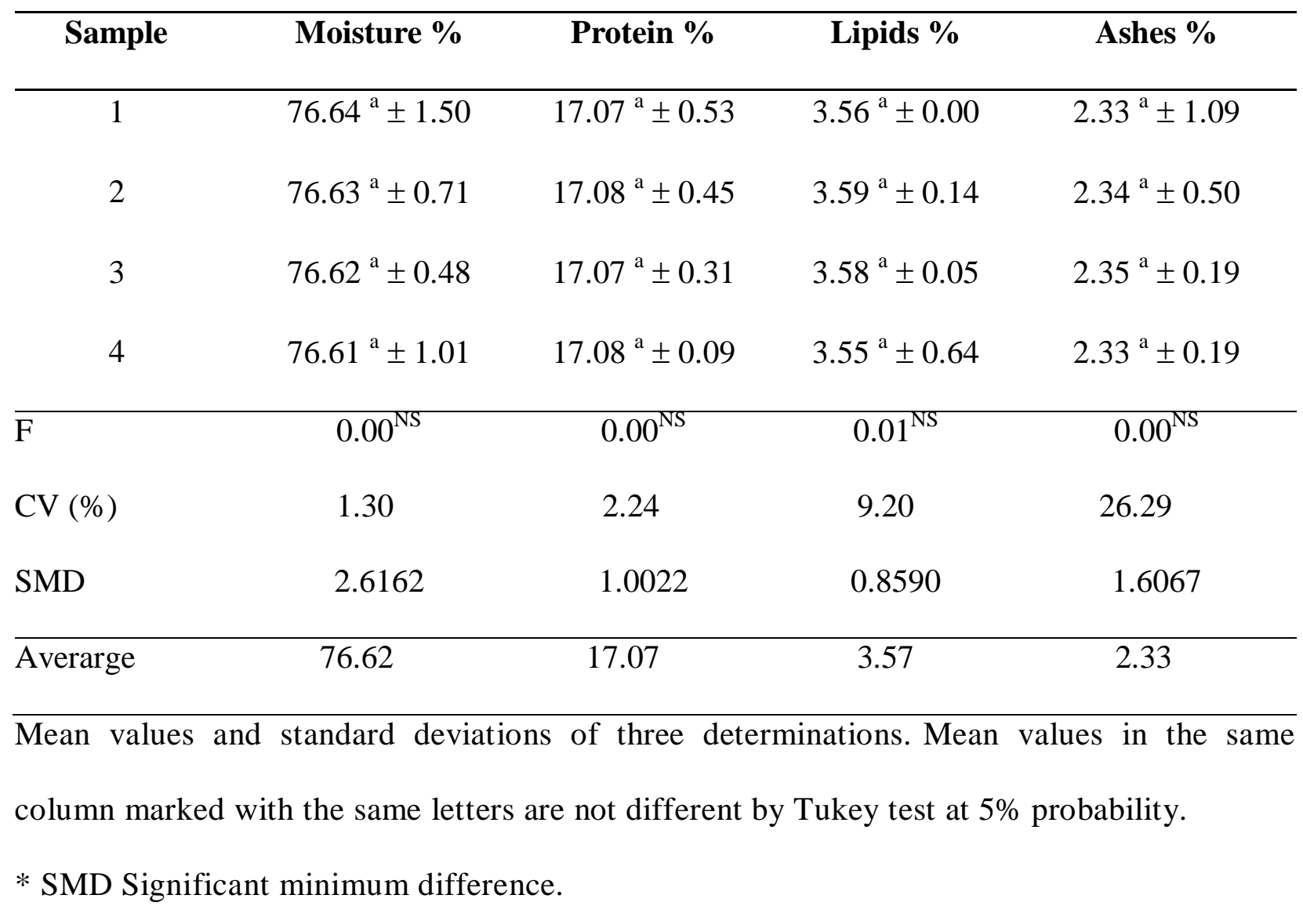

According to Espe \& Lied (1999), the composition of Nile tilapia varies from one species to another and even between the same species, depending on season, type of food, the degree of maturation and sex. It may also vary in the same fish, depending on the analyzed part.

The four batches of the acid silage of Nile tilapia (Oreochomis niloticus), (whole fish with visceras, skin and scales) from Indaiatuba, Sao Paulo, from the harvest showed no difference $(\mathrm{P}>0.05)$ among the samples analyzed (Table 2). The greatest change occurred in the lipid content with a coefficient of variation $(\mathrm{CV})$ of $14.19 \%$, followed, in lesser degree, by the ash content $1.91 \%$, protein with $0.79 \%$ and finally moisture with $0.42 \%$.

Similar results were reported by Abimorad et al., (2009), which working with acid silage of tilapia waste, found in the proximate composition the same of the raw material that had originated it, demonstrating the homogeneity of the final product, which is proven by other authors (CARVALHO et al., 2006). 
Sales et al., Revista Brasileira de Higiene e Sanidade Animal (v.7, n.2) p. 16 - 30, ago - dez (2013)

Table 2. Proximate composition of the full acid silage of Nile tilapia (Oreochomis niloticus), (whole fish with viscera, skin and scales) from Indaiatuba, São Paulo, during the discard period.

\begin{tabular}{ccccc}
\hline Sample & Moisture \% & Protein \% & Lipids \% & Ashes \% \\
\hline 1 & $77.24^{\mathrm{a}} \pm 0.11$ & $16.30^{\mathrm{a}} \pm 0.07$ & $3.28^{\mathrm{a}} \pm 0.50$ & $3.19^{\mathrm{a}} \pm 0.01$ \\
3 & $77.25^{\mathrm{a}} \pm 0.24$ & $16.31^{\mathrm{a}} \pm 0.21$ & $3.27^{\mathrm{a}} \pm 0.36$ & $3.18^{\mathrm{a}} \pm 0.01$ \\
4 & $77.26^{\mathrm{a}} \pm 0.29$ & $16.32^{\mathrm{a}} \pm 0.05$ & $3.26^{\mathrm{a}} \pm 0.05$ & $3.17^{\mathrm{a}} \pm 0.08$ \\
\hline $\mathrm{F}$ & $77.27^{\mathrm{a}} \pm 0.52$ & $16.31^{\mathrm{a}} \pm 0.12$ & $3.25^{\mathrm{a}} \pm 0.69$ & $3.16^{\mathrm{a}} \pm 0.09$ \\
$\mathrm{CV}(\%)$ & $0.00^{\mathrm{NS}}$ & $0.01^{\mathrm{NS}}$ & $0.00^{\mathrm{NS}}$ & $0.14^{\mathrm{NS}}$ \\
SMD & 0.42 & 0.79 & 14.19 & 1.91 \\
\hline Averarge & 0.8515 & 0.3356 & 1.2111 & 0.1585 \\
\hline
\end{tabular}

Mean values and standard deviations of three determinations. Mean values in the same column marked with the same letters are not different by Tukey test at $5 \%$ probability.

* SMD Significant minimum difference.

Thus, the solution of $3 \%$ formic acid $(2 \%)$ in relation to ground fish fish $(98 \%)$, as usually recommended in the literature (Arruda et al., 2006), was judged satisfactory, since it does not change the proximate composition data, being kept constant throughout the storage period of 90 days at a temperature of $27 \pm 3{ }^{\circ} \mathrm{C}$. Abimorad et al., (2009) working with fish waste, recommends a mixture of formic acid and propionic acid in a 1:1 ratio and addition of 5 to $3.0 \%(\mathrm{v} / \mathrm{w})$ on the mass in order to obtain silage which is stable and free of pathogenic microorganisms. Borghese et al. (2008) evaluating the chemical composition and nutritional quality of acid silage (AS), biological silage (BS) and enzymatic silage (ES), elaborated in the discard of Nile tilapia (Oreochromis niloticus), found values (dry matter basis) of: $54.25,53.00$ and $54.50 \mathrm{~g} / 100 \mathrm{~g}$ for crude protein, $12.45 ; 12.25$ and $12.17 \mathrm{~g} / 100 \mathrm{~g}$ for lipid, 8.03, 7.33 and 8.58 $\mathrm{g} / 100 \mathrm{~g}$ for calcium and 4.71, 2.86 and 4.85 
Sales et al., Revista Brasileira de Higiene e Sanidade Animal (v.7, n.2) p. 16 - 30, ago - dez (2013)

$\mathrm{g} / 100 \mathrm{~g}$ for phosphorus, respectively, for AS,

It was observed in Table 3 that lipid content decreased from $3.26 \%$ to $0.48 \%$ after the process of oil removal by decanting, which lasted 15 to 20 days during storage. According to some authors Oliveira et al. (2012), the lipids are immediate sources of energy and essential
BS and ES.

fatty acids for most fish species, and are present in large amounts in planktonic organisms.

Abimorad et al., (2009) correlated the highest concentration of lipid body with the food type, degree of maturity and sex.

Table 3. Proximate composition of defatted acid silage of Nile tilapia (Oreochromis niloticus), (Whole fish with viscera, skin and scales) from Indaiatuba, SP, during the discard period.

\begin{tabular}{ccccc}
\hline Sample & Moisture \% & Protein \% & Lipids \% & Ashes \% \\
\hline 1 & $77.64^{\mathrm{a}} \pm 0.11$ & $17.25^{\mathrm{a}} \pm 0.07$ & $0.48^{\mathrm{a}} \pm 0.20$ & $3.63^{\mathrm{a}} \pm 0.01$ \\
2 & $77.69^{\mathrm{a}} \pm 0.24$ & $17.24^{\mathrm{a}} \pm 0.21$ & $0.49^{\mathrm{a}} \pm 0.19$ & $3.64^{\mathrm{a}} \pm 0.01$ \\
\multicolumn{1}{c}{4} & $77.66^{\mathrm{a}} \pm 0.29$ & $17.25^{\mathrm{a}} \pm 0.05$ & $0.48^{\mathrm{a}} \pm 0.17$ & $3.63^{\mathrm{a}} \pm 0.08$ \\
\hline $\mathrm{F}$ & $77.43^{\mathrm{a}} \pm 0.52$ & $17.21^{\mathrm{a}} \pm 0.12$ & $0.48^{\mathrm{a}} \pm 0.17$ & $3.62^{\mathrm{a}} \pm 0.09$ \\
$\mathrm{CV}(\%)$ & $0.40^{\mathrm{NS}}$ & $0.07^{\mathrm{NS}}$ & $0.00^{\mathrm{NS}}$ & $0.05^{\mathrm{NS}}$ \\
SMD & 0.42 & 0.74 & 37.92 & 1.67 \\
\hline Averarge & 0.8515 & 0.3356 & 0.4784 & 0.1585 \\
\hline
\end{tabular}

Mean values and standard deviations of three determinations. Mean values in the same column marked with the same letters are not different by Tukey test at $5 \%$ probability. * SMD Significant minimum difference

Table 4 illustrates the composition results in $\mathrm{Ca}, \mathrm{P}, \mathrm{Mg}$ and $\mathrm{Fe}$ in the acid silage of Nile tilapia. It is observed that there was no difference $(\mathrm{P}>0.05)$ between the four samples, with a mean of $1.42 \mathrm{mg} / 100 \mathrm{~g}, 0.97 \mathrm{mg} / 100 \mathrm{~g}$, $0.61 \mathrm{mg} / 100 \mathrm{~g}$ and $0.07 \mathrm{mg} / 100 \mathrm{~g}$ respectively, calcium, phosphorus, magnesium and iron. The greatest variation occurred in iron, with a 
coefficient of variation (CV) of $24.74 \%$, ranges from 0.7 to $1.65 \mathrm{~g} \mathrm{mg} / 100$ silage, followed by the content of magnesium, with phosphorus, values between 0.4 to $2.0 \mathrm{mg} / 100 \mathrm{~g}$ $1.63 \%$, phosphorus, with a $1.03 \%$ and finally to of silage, magnesium, 0.5 to $1.05 \mathrm{mg} / 100$ iron, a lesser extent by calcium, with $0.70 \%$. Similar $\quad 0.05$ to $0.09 \mathrm{mg} / \mathrm{kg}$ of silage, no difference is results were obtained by Bueno (2006), who shown $(\mathrm{P}>0.05)$ among the samples. studying the acid fish silage reports that calcium,

Table 4. Composition in $\mathrm{Ca}, \mathrm{P}, \mathrm{Mg}$ and $\mathrm{Fe}$ in of acidic silage of Nile tilapia (Oreochromis niloticus) (whole fish with viscera, skin and scales) from Indaiatuba, Sao Paulo, during the discard period.

\begin{tabular}{ccccc}
\hline Sample & Calcium & Phosphorus & Magnesium & Iron \\
& $\mathbf{m g} / \mathbf{1 0 0 g}$ & $\mathbf{m g} / \mathbf{1 0 0 g}$ & $\mathbf{m g} / \mathbf{1 0 0 g}$ & $\mathbf{m g} / \mathbf{1 0 0 g}$ \\
\hline 1 & $1.41^{\mathrm{a}} \pm 0.01$ & $0.96^{\mathrm{a}} \pm 0.01$ & $0.60^{\mathrm{a}} \pm 0.01$ & $0.08^{\mathrm{a}} \pm 5.77$ \\
3 & $1.42^{\mathrm{a}} \pm 0.01$ & $0.97^{\mathrm{a}} \pm 0.01$ & $0.61^{\mathrm{a}} \pm 0.01$ & $0.05^{\mathrm{a}} \pm 0.01$ \\
4 & $1.42^{\mathrm{a}} \pm 0.01$ & $0.98^{\mathrm{a}} \pm 0.01$ & $0.62^{\mathrm{a}} \pm 0.01$ & $0.07^{\mathrm{a}} \pm 0.01$ \\
\hline F & $1.43 \mathrm{a}^{\mathrm{a}} \pm 0.01$ & $0.97^{\mathrm{a}} \pm 0.01$ & $0.62^{\mathrm{a}} \pm 0.01$ & $0.08^{\mathrm{a}} \pm 0.01$ \\
CV $(\%)$ & $2.00^{\mathrm{NS}}$ & $2.00^{\mathrm{NS}}$ & $2.75^{\mathrm{NS}}$ & $2.00^{\mathrm{NS}}$ \\
SMD & 0.70 & 1.03 & 1.63 & 24.74 \\
\hline Averarge & 0.0261 & 0.0261 & 0.0261 & 0.0453 \\
\hline
\end{tabular}

Mean values and standard deviations of three determinations. Mean values in the same column marked with the same letters are not different by Tukey test at $5 \%$ probability. * SMD Significant minimum difference.

In Table 5 we can compare the corn, as well as the values of chemical score to profile in essential amino acids $(\mathrm{g} / 16 \mathrm{~g} \mathrm{~N})$ of the obtain the quality of those protein sources, new and old silages, soybean meal, casein and obtained for the theoretical reference 
Sales et al., Revista Brasileira de Higiene e Sanidade Animal (v.7, n.2) p. 16 - 30, ago - dez (2013)

(NATIONAL ACADEMY OF SCIENCES, silage of tilapia new and old (with 30 and 90 days of storage) with soybean meal, casein and corn that the latter has low amounts for each amino acid particularly in relation to sulfur as methionine. There are also very low levels of aspartic and glutamic acid. They are very similar to fish meal, when they are made from the same raw material, however, it must be remembered that such products are not obtained from the same raw material, which demonstrates that fish silages provide an optimal response in terms of amino acid profiles, growth rate and feed efficiency (SALES, 1995).

The chemical score (CS) indicated the relationship between the reference protein or default, the order of amino acids in the protein being studied, and the value found for the most limiting amino acid an estimate of biological or nutritive value of protein in the study (SGARBIERI, 1987). The standard protein was defined by the NATIONAL ACADEMY OF SCINCES (1980) as having the following
1980). It was noticed, by comparing the acid concentrations for EAAs $(\mathrm{g} / 16 \mathrm{~g} \mathrm{~N})$ Isoleucine 4.2, Leucine 7.0, Lysina 5.1, Total súlfur 2.6, Total Aromatics 7.3, Treonine 3.5, Valine 4.8, Tryptophan 1.1, Histidine 1.7 e Aspartic Acid 7.8 (Table 5).

Espe \& Lied (1999) reported that the handmade silage has high amounts of essential amino acids, such as lysine (5.54 g / $\mathrm{kg})$, histidine $(5.33 \mathrm{~g} / \mathrm{kg})$ and glutamic acid $(6.04 \mathrm{~g} / \mathrm{kg})$, making it an excellent alternative for adding value to biowate from fish solid waste.

It was observed that the decomposition of amino acids was higher in silage stored for 90 days than in the samples taken during the first 30 days, avoiding loss of aminoacids, during which it was found a smaller number of decomposed products, particularly essential amino acid as leucine, isoleucine, lysine and tryptophan, affecting significantly the weight gain of animals in relation to silage stored for long periods of time (SALES, 1995). 
Table 5. Profile of amino acids (g/16 g N) and chemical score of protein sources used for the preparation of diets, whose determination was made by ion exchange.

\begin{tabular}{|c|c|c|c|c|c|c|}
\hline Amino acid & New Silage & Old silage & Soybean meal & Casein & Corn & $\begin{array}{c}\text { Standard } \\
1\end{array}$ \\
\hline Isoleucine & 5.64 & 3.80 & 1.81 & 5.4 & 2.5 & 4.2 \\
\hline Leucine & 9.27 & 6.00 & 3.69 & 10.2 & 10.3 & 7.0 \\
\hline Lysine & 9.90 & 6.80 & 2.65 & 7.8 & 2.2 & 5.1 \\
\hline Methionine & 3.05 & 2.70 & 0.64 & 2.8 & 1.9 & - \\
\hline 1/2 Cystine & 1.22 & 0.98 & - & 0.2 & - & - \\
\hline Total súlfur & 4.27 & 3.90 & 0.64 & 3.0 & 1.9 & 2.6 \\
\hline Tyrosine & 3.20 & 3.12 & - & 6.1 & - & - \\
\hline Phenylalanine & 4.36 & 4.10 & 2.11 & 5.6 & 3.6 & - \\
\hline Total Aromatics & 7.56 & 7.22 & 2.11 & 11.7 & 3.6 & 7.3 \\
\hline Threonine & 4.35 & 3.90 & 1.80 & 4.9 & 2.9 & 3.5 \\
\hline Valine & 5.25 & 5.12 & 2.05 & 6.9 & 3.9 & 4.8 \\
\hline Serina & 3.80 & 3.60 & 2.42 & 6.8 & 3.7 & - \\
\hline Alanine & 8.10 & 4.23 & 2.12 & 3.2 & 6.3 & - \\
\hline Tryptophan & 1.06 & 0.60 & - & - & - & 1.1 \\
\hline Histidine & 2.20 & 2.10 & - & 2.9 & - & 1.7 \\
\hline Arginine & 8.35 & 7.10 & 3.17 & 4.1 & 3.2 & - \\
\hline Glutamic Acid & 18.27 & 12.30 & 8.82 & 27.4 & 17.2 & - \\
\hline Aspartic Acid & 12.30 & 7.00 & 5.13 & 8.6 & 5.4 & 7.8 \\
\hline Glycine & 8.12 & 6.05 & 1.98 & 1.9 & 3.0 & - \\
\hline Proline & 4.25 & 3.90 & 2.33 & 10.0 & 7.2 & \\
\hline Chemical Score & 96.30 & 54.5 & 24.6 & 110.25 & 43.1 & \\
\hline
\end{tabular}

1 Theoretial Standard (NATIONAL ACADEMY OF SCIENCES, 1980).

Covalent bonds between proteins

and oxidized products can destroy the amino acids such as tryptophan, oxidize methionine and bind lysine to other compounds making them unavailable amino acids (NELSON \&
COX, 2000). Probable explanation for this reduction of nutritional value may be the fact that free amino acids are quickly diverted from protein synthesis and enter the catabolic pathway, getting more available to be used as an 
Sales et al., Revista Brasileira de Higiene e Sanidade Animal (v.7, n.2) p. 16 - 30, ago - dez (2013)

energy source than the intact proteins

(VIDOTTO, 2001; VIDOTTO et al., 2003). Free amino acids in the presence of

\section{Conclusion}

The results demonstrate the possibility of the use of the acid silage prepared from the whole fish discard of Nile tilapia(Oreochromis niloticus) as a protein ingredient in balanced rations for animal feed, as a partial substitute for fishmeal, and that silage shoulder be consumed until 30 first days of preparation to avoid amino acids decomposition.

\section{References}

ABIMORAD, E.G. et al., Silagem de peixe em ração artesanal para tilápia-do-Nilo.

\section{Pesquisa}

Agropecuária

Brasileira, vol.44 N 5 Brasília May 2009. http://dx.doi.org/10.1590/S0100-

204X2009000500012

AOAC. Association of Official Analytical Chemists. HORWITZ, W. (Ed). Official

Methods of Analysis, 17.ed. Arlington, Virginia, USA, 2000. v. 1 and v. 2. hydroxyl from the sugar present Maillard reaction resulting in decreased nutritional value of silage (FAGBENRO \& JAUNCEY, 1998).

ARRUDA, L.F. et al. Aspectos nutricionais da silagem de tilápia-do-nilo (Oreochromis niloticus). Food Science and Technology, (Campinas). On-line version ISSN 1678$457 X$.

Ciênc.

Tecnol.
Aliment., vol.26 no.4 Campinas Oct./Dec.

2006. $\quad$ http://dx.doi.org/10.1590/S010120612006000400006

BARBOSA, J. C.; MALDONADO JR. W.; AgroEstat - System for Statistical Analysis of Agronomic Trials, Version 1.0, 2010.

BEERLI, E.L. et al. Silagem ácida de resíduos de truta (Oncorhynchus mykiss), com utilização de ácido muriático. Ciência e Agrotecnologia, v.28, n.1, p.195-198, 2004. Disponível em: http://www.scielo.br/pdf/cagro/v28n1/a26.pdf. Acesso em 18 set 2012.

BERAQUET, N.J.; GALACHO, S.A.A. Composição, estabilidade e alterações na fração protéica e no óleo de ensilados de resíduos de peixe e de camarão. Col. ITAL, v. 13, p. 149-74, 1983. 
Sales et al., Revista Brasileira de Higiene e Sanidade Animal (v.7, n.2) p. 16 - 30, ago - dez (2013)

BORGHESI, R. et al. Apparent digestibility coefficient of protein and amino acids of acid, biological and enzymatic silage for Nile tilapia (Oreochromis niloticus). Aquaculture Nutrition, v. 14, n. 3, p.242-248, 2008.

$$
\text { Disponível }
$$

em:

$<$ http://onlinelibrary.wiley.com/doi/10.1111/

j.1365-2095.2007.00523.x/abstract >. Acesso

em: 27 abr. 2012. doi: 10.1111/j.13652095.2007.00523.x.

BUENO, J.R. Silagem ácida de resíduos da filetagem de tilápia em dietas de alevinos de piauçu Leporinus macrocephalus. 2006. 45f. Dissertação (Mestrado em Aqüicultura)

- Curso de pós-graduação em Aqüicultura, Universidade Estadual Paulista.

CARVALHO, G.G.P. et al. Silagem de resíduo de peixes em dietas para alevinos de tilápia do Nilo (Oreochromis niloticus). Revista

Brasileira de Zootecnia, v.35, n.1, p.126-130, 2006. Disponível

em:http://dx.doi.org/10.1590/S151635982006000100016. Acesso em 18 set 2012.
ESPE, M.; LIED, E. Fish silage prepared from different cooked and uncooked raw materials: Chemical changes during storage at different temperatures. Journal of Science Food and Agriculture, v. 79, No 2, p. 327-332, 1999.

ESPIDOLA FILHO, A. Aproveitamento do resíduo sólido de peixe, camarões e bivalvos como ingredientes de ração para aquicultura. São Paulo, 1999. 224f. Tese de Doutorado em saneamento ambiental. Universidade de Mackenzie.

FAGBENRO, O.A.; JAUNCEY, K. Physical and nutritional properties of moist fermented fish silage pellets as a protein supplement for tilapia (Oreochromis niloticus). Animal Feed Science and Technology, v.71, n.1-2, p.11-18, 1998. Disponível em: <http://www.sciencedirect.com/science/article/p ii/S0377840197001235>. Acesso em: 27 abr. 2012. doi: 10.1016/S0377-8401(97)00123-5. MACH DIEP, T.N. \& NORTVEDT, R. Chemical and nutritional quality of silage made from raw or cooked lizard fish (Saurida undosquamis) and blue crab (Portunus pelagicus). Journal of the Science of Food and Agriculture, v.89, n.15, p.2519- 
Sales et al., Revista Brasileira de Higiene e Sanidade Animal (v.7, n.2) p. 16 - 30, ago - dez (2013)

2526, 2009. Disponível em: 174p. Tese (Doutorado) (Universidade <http://onlinelibrary.wiley.com/doi/10.1002/jsfa $\quad$ Estadual de Campinas).

$.3761 /$ abstract>. Acesso em: 27 abr. 2012. doi:

SGARBIERI, V.C. Food and nutrition: a 10.1002/jsfa.3761.

factor to health and development. 2nd

MOORE, I; STEIN, W.H. Chromatographic determination of amino acids by use of automatic recording equipaments. Methods in

Enzimology, v.6, p.919-931,1963.

NATIONAL ACADEMY OF SCIENCES.

National Research Council. Institute of Laboratory Animal Resources. ILAR News, Washington, v. 20, n. 3, p.11-15, 1980.

NELSON, D. L.; COX, M.M. Lehninger principles of biochemistry. New York: Worth Publication, 2000, 145p.

OLIVEIRA, A.L.T. et al., Alternativa sustentável para descarte de resíduos de pescado em Fortaleza. Revista Brasileira de Higiene e Sanidade Animal. v. 6, n. 2, p. 97 - 119, 2012.

SALES, R.O. Processamento, caracterização química e avaliação nutricional da silagem da despesca da tilápia do Nilo (Oreochromis niloticus) em dietas experimentais com ratos, (1995). ed. Campinas: UNICAMP, 1987. 387p.

SPACKMANN, D.H. et al. Automatic recording apparatus for use in the cromatography of amino acids. Cereal Chemistry, v. 30, n. 7, p. 1190-1206, 1958. SPIES, J.R. Determination of tryptophan in proteins. Analytical Chemistry, v. 39, p. 14121415, 1967.

VIDOTTI, R.M. Produção e utilização de silagens de peixe na nutrição do pacu (Piaractus mesopotamicus), 2001. 65p. Tese (Doutorado) - Centro de Aqüicultura, Universidade Estadual Paulista "Júlio de Mesquita Filho", Jaboticabal, 2001.

VIDOTTI, R.M. et al. Amino acid composition of processed fish silage using different raw materials. Animal Feed Science and Technology, v.105, n.1, p.199-204, 2003. Disponível em: <http://www.gipescado.com.br/banco\%20teses dissert/artigos/afst_105(1-4)-199-204.pdf>. 
Sales et al., Revista Brasileira de Higiene e Sanidade Animal (v.7, n.2) p. 16 - 30, ago - dez (2013) Acesso em: 28 abr. 2012. doi: 10.1016/S0377-

8401(03)00056-7. 